\title{
Social and Cultural Context Affecting the Activities of Women Painters of Pahlavi Era (1925-1978)
}

\author{
Azadeh Alipoor Heris ${ }^{1} \&$ Abolghasem Dadvar ${ }^{1}$ \\ ${ }^{1}$ Art Faculty, Azzahra University, Tehran, Iran \\ Correspondence: Azadeh Alipoor Heris, Art Faculty, Azzahra University, Tehran, Iran. E-mail: \\ Alipourazadeh09126126864@gmail.com
}

$\begin{aligned} & \text { Received: December 23, } 2015 \quad \text { Accepted: April 2, } 2016 \quad \text { Online Published: April 27, } 2016 \\ & \text { doi:10.5539/jpl.v9n3p1 }\end{aligned}$ URL: http://dx.doi.org/10.5539/jpl.v9n3p1

\begin{abstract}
Different factors were affecting the presence of women during the Pahlavi era. In new structures after the constitutional period and along with the absolute modernism of Pahlavi, discourses changes were made based on democracy, socialism, Shia resistance and autonomy, court to government and political figures to people. During this period the role of women was formed on the basis of their social position and in their gender approach it changed from a $<$ class in itself $>$ to a $<$ class for self $>$. The consequences of social contexts led to witness more active presence of women during Pahlavi era compared with the past periods particularly in the visual arts arena; so that the history of the Tehran galleries from 1953-1978 which reflects their activities during that time confirms this fact. The purpose of the present essay is to analyze the social contexts which have attracted women from margin to the center and attending to them since no study has been done in this respect seems essential and it's an attempt to answer the question that what social contexts have been influential in boosting up the presence of women especially women painters of Pahlavi era? In this research the data collect is library type and filed study and it has been compiled in a comparative descriptive-analytic method, the origin and social contexts of the women painters of the Pahlavi era whose works were displayed were studied and analyzed and it can be inferred that the presence of supportive men in families, education, social context, urban life, publicizing the culture thanks to the cultural foundations and media, the actual and legal presence of the queen, government support due to cultural policies, women social movements, and the transformation of the women role in twentieth century had decisive role on enhancing the social position of women particularly the role of the women painters of the second Pahlavi era.
\end{abstract}

Keywords: social contexts, women painters, galleries, education and social class, Pahlavi era, and cultural policies

\section{Introduction}

The painting art of Iran which for centuries was limited to illumination and illustration and mural, was a school-oriented art which was mostly under the protection of the rulers and its tastes, position, and geographic center was in direct relation with the change of governments and the individualistic presence of the artist-signature- and also the role of the women painters is very rare in it. The acquaintance of the Iranian painting with western art started from the Safavi Era. After that and during the late Ghajar era as a result of the acquaintance of Iranian artists such as Mozzayan no Aldole and Kamalol Molk with western art the general and modern painting instruction methods were planned. And during the same time and on the basis of the extant documents the Iranian women who were mostly inside the house and particularly the middle class plus spent their free time on manual industries and sewing- by the help of the open minded fathers, brothers and scarcely husbands- if they were literate dealt with poetry, calligraphy and painting and rarely music. By the occurrence of the constitutional revolution a huge change happened in the status of the Iranian women. Increasing publicizing of the culture and the education by the rise of civil demands; moved women outside the houses and this released energy by the establishment of the Pahlavi government along with the absolute modernism and the enhancement of the will towards the power of women led to the rise of their social position compared with past periods so that in the filed of professional visual arts and particularly in painting, during 1966-1978 we observe the display of 166 works of women in Tehran galleries. The galleries which were founded during 1949-1977 the present research tries to identifying the social contexts of women presence and affecting factors in its enhancement and 
its position with a look at active presence of women painters in visual arts field so that the analysis of this issue provide the answer to the question that what were the social contexts of women painters in Iran during the Pahlavi era? To put it in nutshell, the data about these women has been analyzed along with the social and cultural history of the women based on the art, women and painting.

\section{Review of the Literature}

In contrast to the social and cultural position of the women during the Ghajar Era which has attracted considerable number of researches to it unfortunately, the position and the status of the women during the Pahlavi era given the controversial and critical perspectives about this period has become isolated and abandoned. In terms of the women activities context during the Pahlavi era we may refer to <power and representation: a revision of women activities during King Reza period $>$ written by Afsane Najmabadi, in Ghoftegoo magazine 2005 and another essay titled $<$ a look at the position of Iranian women in Pahlavi era from 1921-1953 written by Somayye Abbasi and Mansoor Moosavi in women research magazine No.1393 might be referred to. In terms of the coffee house painting biennials and ultimately over the past two decades the life and activities of the women painters and its artistic foundations have been attended. Among them we may refer to $<$ Ghahve Khane painting: faithful despite all temptations> written by Kazem Chalipa in Tandis two weeklies in 2010 and an essay <Iran Daroodi $>$ Of contemporary Iranian artists essays series, by the attempt of Hassan Morizi Nejad in Tandis two weeklies in 2006 can be referred to. Similarly some facts are evaluable in these periods such as in the work in" Between two points! "Written by Iran Daroodi (1994) and in the "Book a girl from Iran" written by Sattareh Farman Farmiyan (2007) but in terms of the social history of the painting in this era and particularly the social contexts of the women painters of this period there exists no definite book or essay.

\section{Methodology of the Research}

The present study is among comparative, descriptive types of research and the data collect is library type and field study and it has been compiled in a comparative descriptive-analytic method, the origin and social contexts of the women painters of the Pahlavi era. In this research the name of 166 women artists have been collected from the history of the art galleries and have been studied next to the main course of study (tables 1 and 1.2) and the research population consisted of the women painters of the second Pahlavi era whose works have been displayed in Tehran art galleries (table 2). From the research population 42 persons $(25 \%$ of the statistic population) were randomly selected and the data such as the place of birth, place of education, family lineage and the professional resume were studied and analyzed. The results of the analyses and the analogies among most of them facilitated the extraction of influential social contexts in women painters activities of Pahlavi era. 
Table 1. The name of women painters or artists in the realm of visual arts whose names have been recorded in the history of the Tehran art galleries

\begin{tabular}{|c|c|c|c|c|c|c|c|}
\hline & First and last name & & First and last name & & First and last name & & First and last name \\
\hline \multirow[t]{2}{*}{1} & Ramona darbin & 29 & Kelara Abkar & 57 & Shirin Javid (Bakhtiyar) & 85 & Monir \\
\hline & & & & & & & Noshin(Masome,Seyhon) \\
\hline 2 & Fereshte Gazizade & 30 & Forozande Pahlevan & 58 & Simin Khakpor & 86 & Ghazale Alizadeh \\
\hline 3 & Fozi Tehrani & 31 & Leyla Samari & 59 & Tamila Shahinfar & 87 & Behjat Sadr \\
\hline 4 & Sonia balasanian & 32 & Behnaz khoshkish & 60 & Parisa Bahmanyar & 88 & Maryam Javaheri \\
\hline 5 & Ayda almasian & 33 & Azita Ghafoori & 61 & Nahid Keramati & 89 & Leili Matin daftari \\
\hline \multirow[t]{2}{*}{6} & Parmis akhavan & 34 & Mitra & 62 & Faride Emad zadeh & 90 & Hasmik Nersesian \\
\hline & & & Farmanfarmian & & & & \\
\hline 7 & Fereshte asefi & 35 & Pari Mohammadi & 63 & Mahin nor mah (Ayatollahi) & 91 & Talie Kamran \\
\hline 8 & Simin razavian & 36 & Nosrat Motamedi & 64 & Polet (afsane baghaei) & 92 & Shahla Arbabi \\
\hline 9 & Nafise tahbaz & 37 & Sedighe Noori & 65 & Leilit terian & 93 & Mansooreh Hoseini (Nazhfar) \\
\hline 10 & $\begin{array}{l}\text { Parvane Varzande(rad } \\
\text { mard) }\end{array}$ & 38 & Mina Shahmanesh & 66 & $\begin{array}{l}\text { Monir shahroodi faraman } \\
\text { farmaian }\end{array}$ & 94 & Violet Mottahedeh \\
\hline 11 & Jinoos Karimi & 39 & Zienab Emami & 67 & Fatemeh Emdadian & 95 & Helen Ragheb \\
\hline 12 & $\begin{array}{l}\text { Zohre } \\
\text { (Rahnavard) }\end{array}$ & 40 & Fakhri Angha & 68 & Janet Mikhailei & 96 & Iran Daroodi \\
\hline 13 & Goli Mogtader & 41 & Minoo modabber & 69 & Farangis Ari & 97 & Sima kuban \\
\hline 14 & Barbara Zahri & 42 & Pari Mohana & 70 & Minoo Asadi & 98 & Mehrin Mehran \\
\hline 15 & $\begin{array}{l}\text { Zahra khajeh } \\
\text { noori(Farzaneh) }\end{array}$ & 43 & Aazam Amiri & 71 & Alam Mokhtari & 99 & Mehrangiz Yasemi \\
\hline 16 & Rooya Behzadi & 44 & Malihe Moayeri & 72 & Elahe Aroozi & 100 & Shila Akhavan Saleh \\
\hline 17 & Shirin Tabesh far & 45 & Zohre Totonchian & 73 & Shahla Habibi & 101 & Payande Shahande \\
\hline 18 & Maryam Ehsaee & 46 & Shahin Hannane & 74 & Nahid Partovi & 102 & Jale Poor ahang(ahang) \\
\hline 19 & Shahrzad Shanazi & 47 & Parvin Farzaneh & 75 & Jinoos Monfared & 103 & Mahin dohkt Azima (Barzin) \\
\hline 20 & Niloofar Poozeshi & 48 & Hengame Golestan & 76 & Giti Roosta & 104 & Giti Navrarn (Novin) \\
\hline 21 & Tahmine Mir mirani & 49 & Jamile Hashemi & 77 & Soodabe Ganjei & 105 & Soosan Farjam \\
\hline 22 & Maryam firooz & 50 & Anoosh Mohseni & 78 & Shirin Dabir alaee & 106 & Giti Maarefi \\
\hline 23 & Atefeh Vakili & 51 & Mitra Farshad & 79 & Faride Lashaei & 107 & Soodabe Sharafshahei \\
\hline 24 & Khanom Radpei & 52 & Nooshin Farshad & 80 & Suzan Pligram & 108 & Parvane Etemadi \\
\hline 25 & Nahid Saliani & 53 & Anet Farahmand & 81 & Nasrin Irvani & 109 & Nazi Atri \\
\hline 26 & Soori Shogi & 54 & Mahnaz Gazanfari & 82 & Mina Vosoogi noori & 110 & Margaret Jahan dar \\
\hline 27 & Faride Sabi (golbahar) & 55 & Homa zand & 83 & Samila Amir ebrahimi & 111 & Moalia Amiri \\
\hline 28 & Minoo Motamed gorji & 56 & $\begin{array}{l}\text { Farzane } \\
\text { (Niazei) }\end{array}$ & 84 & Linda Homayoon & 112 & Gizela Warga(Silaiee) \\
\hline
\end{tabular}

Note: *Names written in parenthesis have several states, some have the last name of their spouses, some the name the have adopted after the revolution and some are the artistic names of these people 
Table 1.2. The name of women painters or artists in the realm of visual arts whose names have been recorded in the history of the Tehran art galleries

\begin{tabular}{llll}
\hline & First and last name & & First and last name \\
\hline 113 & Pari Ale davood & 140 & Maryam Zandi \\
114 & Manije Armin zade & 141 & Mahin Taban \\
115 & Fereshte Noori & 142 & Sima Barzegar \\
116 & Effate Roozbeh & 143 & Faride Kado \\
117 & Agdas RiazeI & 144 & Homa Khoshbin \\
118 & Shiva Ehsani & 145 & Ema Abrahimian \\
119 & Prvane Marzban & 146 & Mitra Sheibai \\
120 & Jale Poorian & 147 & Nahid Hagigat \\
121 & Robabe Noorian & 148 & Maryam Jazayeri \\
122 & Parto Vahid (khosravi) & 149 & Soodabe Ghasemloo \\
123 & Faride Morshed & 150 & Mina Bamshad \\
124 & Mary Shayans & 151 & Ronate Froorak (bloori) \\
125 & Soosan Varjavand & 152 & Dil ichi \\
126 & Nasrin Dokht arj & 153 & Hoorakhsh Taban \\
127 & Manije Osia & 154 & Floor Abkar \\
128 & Hayde Golami & 155 & Badri Alaee \\
129 & Ashraf Allame zade & 156 & Parvin Sepehr \\
130 & Fatemeh Heidari & 157 & Vahe Moradian \\
131 & Sedige khorasani & 158 & Shieda Saleh \\
132 & Farh Notash & 159 & Zita Jalayer \\
133 & Iran Eslam doost & 160 & Sheri Shams \\
134 & Mahvash Asadian & 161 & Mehri Rakhsha \\
135 & Sima Bina & 162 & Toosi Haeri \\
136 & Minoo Vaseghi & 163 & Shahla Nafisi \\
137 & Homa BanaeI & 164 & Fereshteh Sholevar \\
138 & Azam Koosha (Iraj poor) & 165 & Leili Khosravi \\
139 & Sedige Nik pey & 166 & Magda hatami chanI \\
\hline & & & \\
& & \\
12 & & \\
12 & &
\end{tabular}


Table 2. Name of the Tehran galleries with the establishment date, founders and their address

\begin{tabular}{|c|c|c|c|c|}
\hline & Name of the Gallery & Date & Founder & Place in Tehran.Iran \\
\hline 1 & $\begin{array}{l}\text { Apadana(kashane } \\
\text { honarhaye ziba) }\end{array}$ & 1949 & $\begin{array}{l}\text { Mahmood javadi poor hossein kazemi, } \\
\text { hooshang ajodani }\end{array}$ & $\begin{array}{l}\text { East corner, Bahr street, Shah reza conjunction (Engelab } \\
\text { street before piche shemiran) }\end{array}$ \\
\hline 2 & Honare Jadid & 1955 & Seyyed ali taba & Bahr st. Tab station \\
\hline 3 & Kabood & 1960 & Parviz tanavoli & Pahlavi St. (valiasr) \\
\hline 4 & $\begin{array}{l}\text { Talare Iran } \\
\text { (Ghandriz) }\end{array}$ & 1964 & Eleven students of the art university & $\begin{array}{l}\text { underground restaurant in front of the main entrance of the } \\
\text { Tehran University }\end{array}$ \\
\hline 5 & Boorgez & 1964 & $\begin{array}{l}\text { Miss Polet(French). After marriage } \\
\text { with Kavoos baghaee changed her } \\
\text { name to Afsane }\end{array}$ & $\begin{array}{l}\text { the first floor of a building Takhte jamshid (taleghani) } \\
\text { which was later moved to Vila juncture west corner of } \\
\text { Sorraya }\end{array}$ \\
\hline 6 & Seyhon & 1966 & Minoo nooshin (masoome seihoon) & Park st. (Vozara) $4^{\text {th }}$ alley \\
\hline 7 & Negar & 1967 & Afsane Bagayi(Hoveyda) & Soraya (Somayye Iranshar juncture) No.132 \\
\hline 8 & Niyazi & 1968 & Manochehr Niyazi & $\begin{array}{l}\text { souther corner of Ferdosi square, next Loan tur company } \\
\text { first floor, No353 }\end{array}$ \\
\hline 9 & Talare Nagsh & 1968 & $\begin{array}{l}\text { Managemnt of Iran islam Hamid Iran } \\
\text { doost }\end{array}$ & $\begin{array}{l}40 \mathrm{~m} \text { befor Navvab street, before, Kandi squar (Tohid } \\
\text { square)next to research center of Tehran University training } \\
\text { sciences No88 }\end{array}$ \\
\hline 10 & Solivan & 1969 & Mohammadtagi Siyahatgar & Valiasr St. Amir Akram juncture \\
\hline 11 & Aftab khane & 1970 & Art and culture ministry & $\begin{array}{l}\text { Rozvelt St. (Mofatteh) high education academy (teacher } \\
\text { training university) No.154/1 }\end{array}$ \\
\hline 12 & 92 house & 1970 & Hoseyn Mahjobi & Shahreza (Azadi)Abooreyhan St. Tir junctureNo.92 \\
\hline 13 & Lito & 1971 & Khanom goli mogtader & Aban St. No.3 \\
\hline 14 & Gallery Tehran & 1973 & Nahid partovi & $\begin{array}{l}\text { Ghasr juncture Beheshti St. Abbas Abad St. No. } 332 \text { second } \\
\text { Floor }\end{array}$ \\
\hline 15 & Zarvan & 1973 & Golam reza mogaddam & Kakh shomali, (Felestin)Kakh squar Ebtehaj St. No.39 \\
\hline 16 & Mehrshah & 1974 & Art and culture ministry & $\begin{array}{l}\text { Farah shomali, (Sohrevardi) Mehrshah St. (Khorramshahr) } \\
\text { Nobakht juncture (Arabali ) }\end{array}$ \\
\hline 17 & Mani & 1974 & $\begin{array}{l}\text { Jale poorhang pari ale davoodand } \\
\text { Saeed Yazdanian }\end{array}$ & $\begin{array}{l}\text { Pahlavi St. (Valiasr) Amiakra juncture. Koorosh building } \\
\text { third floor }\end{array}$ \\
\hline 18 & Takhtejamshid & 1974 & Art and culture ministry & $\begin{array}{l}\text { Third building of the art and culture ministry Takhte } \\
\text { jamshid (Taleghani St)corner of Bandar Pahlavi (Bandar } \\
\text { anzali) next cinema Paramount }\end{array}$ \\
\hline 19 & Saman & 1975 & $\begin{array}{l}\text { Mehrmah farmanfarmaian Hayede } \\
\text { hakimi, mehri sabeti Tania foroogi }\end{array}$ & $\begin{array}{l}\text { Abe Karaj Bolvar, Bolvar elizabet-(Bolvare keshavarz) } \\
\text { Under the block two of the saman building }\end{array}$ \\
\hline 20 & City & 1976 & Bijan basiri Ali rafee & Bozorg mehr No.86 \\
\hline 21 & zand & 1976 & Homa zand Feriedoon Av & $\begin{array}{l}\text { Jordan above Zafar, Toor alley,No.32 after a year was } \\
\text { moved to ASP in Mohammad reza }\end{array}$ \\
\hline 22 & Korte & 1976 & Mis radpei Kamran Katoozian & The end of park St. Vozara St,No.431 \\
\hline 23 & Shikh & 1977 & Golnar Sheikh & Bokharest St. $8^{\text {th }}$ St. No.32 \\
\hline 24 & Faslha and yadha & 1977 & Mostafa Moeenin Aragi & $\begin{array}{l}\text { Takhte Tavoos St. (Motahhari)Miremad St. eleventh St. } \\
\text { No.26 }\end{array}$ \\
\hline
\end{tabular}




\section{Social and Cultural Context Affecting the Activities of Women Painters of Pahlavi Era (1925-1978)}

From among the 42 selected sampling of the research 22 that is a bit more than the half were born in Tehran and after Tehran were cities in order of Rasht (3 persons), Mashad (2persons), Shiraz (2persons), Kermanshah (2 persons), and Arak, Abadan, Ghazvin, Bandar Anzali, Lahijan, Tabriz, Borujerd, Esfehan, and Urumiye each one with one person. Among them some were also born outside Iran and the cities New York and London each one had one person. The corollary is that they were born in large cities. By analyzing the last name of these people we found out that they had names belonging to reputed and influential families from middle and middle plus social class from among them we may mention: $<$ Farman Farmaiyan $>,<$ Matin Daftari $>,<$ Sadr $>,<$ Etezadi $>$, $<$ Javid $>$.

Among the names there are also some names of the Armynion and Jewish names such as: $<$ Nersesian $>$, $<$ Mikhaili $>,<$ Mottahede $>$. And the fathers and husbands of the women painters were mostly from official system, military and court families or the open minded people of the Ghajar era and the first Pahlavi era. Most of them had spent their childhood in different small cities and their adolescence in Tehran and had studied at high education and worked at different institutions and most of them after graduating from the Universities had continued their specialized art courses in foreign countries. The other point in this respect is about the frequency and spread of art galleries of Tehran in the northern part of the Tehran city during the Pahlavi era; to some extent shows the cultural center of the artists and those who care about it. The findings of the research brought us up to this point to extract the social contexts and study them. Later in the work we would concisely refer to the social context and women related field of the late Ghajar in order to understand the social contexts of women which were inherited by the Pahlavi era.

\subsection{Social and Cultural Contexts of Women from Constitutional Revolution up to the Late Ghajar}

The constitutional revolution despite a fleeting and dimly bright commencement of an era had been able to promise management of the nation, political and educational operations. But in spite of that the roots of this revolution returned to the gradual spread of west in Iran. From among the ramifications of the constitutional revolution up to the Pahlavi era were the gradual emergence of women movements and different social classes. The constitutional revolution changed the court into government and the men into people. And for the same reason the presence of women at social contexts increased to a large extent. The attention of the high class families and middle plus class families to the necessity of providing education to women, the establishment of papers and press and the foundation of different women hubs and finally led to the more dynamic presence of women at political and economic activities compared with the past from the constitutional revolution to the late Ghajar era. By the rise of the number of educated women and aware of their social position and the gradual appearance of middle class in the social context of Iran the cultural level of the families improved to a large extent. Fight against the interference of foreign countries such as Russia and the supporting the national government are among the acme of the women activities in this period. The presence of photography and cinematograph and its rise in the late Ghajar era converted many of the views of the men who had not been to the west and women who were isolated inside the house and the instruction of the art of painting started from the high school level in this period. Among them the presence of non-Muslim fellow-Iranian women in boosting up the art culture and the improvement of the role of women in this respect is considerable. The conspicuous presence of clergy men in the political and social contexts of the society of the beginning of the revolution and the confrontation of them in new women movements and social trends of the constitutional revolution and the suffragette and attaining higher posts and positions. despite the cooperation of women in the constitutional revolution and by its victory women were put aside but they never quit proceeding their presence and did their best to remind the parliament of their social rights and social role and social freedom. In this period women in particular the women from great family lineage, open minded, well-off and modernist in addition to engagements in poetry, calligraphy, handwork, and sewing played musical instruments and did painting. Their support of the art has been recorded in the history. Some of them have learnt from great master of art and some were apprenticed. In this period, Germany, England, and Russia were doing lottery over their rights and benefits in Iran. and America was on the rise as a new power in the world and these foreign states engaged Iran in local and world wars as well as famine and finally Iran was a defeated classic government in 1920. Ultimately, at the end of the fire set by the competition between Russia and England led to the Coup by the king Reza and his empowerment. During the Pahlavi era Iran in addition to making attempts for preserving the national integration and state modernism with archaism and anti-racism and a superficial adoption of modernism took steps in this regard while becoming aware of the role of women in its cultural policies. And for the same reason apposite social contexts for the presence of women painters can be divided into two basic groups. First, contexts with more general and world wide context and analogous with those of other countries but at different times 
developed and evolved that are referred to as general context and second one is the local and aboriginal contexts which were endogenous and were special to social atmospheres of the Pahlavi era and the women painters of that era which we would analyze them in due respect.

\subsection{General Contexts}

\subsubsection{Women Role Metamorphosis in Twentieth Century with a Look at Family and Gender Clichés}

Women entered the twentieth century while due to the thoughts originated from the ancient Greek confronted with the masculinity of the enlightenment era of science and the corollaries of the industrial revolution found them exiled into the house ambience and downgraded apart from any sort of sustainable economic income and civil right. The origin of the downgrading of the women and the conversion of family format because of the urbanity was consequently the change of the society. From among the various sociological views concerning the family, among the conservative views of the theoreticians of the 1950 decade the refusal view is conspicuous and commensurate with that of Iranian family. In this view the social position of the husband's job determines the social position of the family and the social position of the women is formed by the social position of the husband's job and not their social activities. (Azazi, 2011)

At the same time with the end of the Second World War and as a result of the change of world wide view the subject of fulfilling the women right was considered much more seriously. And in many countries the subject of allotting political right to women was put forward. In Iran the government became responsible to form a commission to look after the man and woman right equity issue in the interior ministry. (Moska gaeta, 1991)

In the midst of the twentieth century the condition of the western world got different. In the case of women this changed accompanied with their presence of them at university and the new world of occupation. The term gender was implemented after the $80^{\mathrm{s}}$ decade afterwards within the social studies and the reference to women problems increased in social discourses and these arguments reached its pinnacle with the feminism movement in the late 1980s in Iran for centuries despite the legality of the social and official rights during the Pahlavi era; the related rules and conventions about the marriage and the family give more power to men women only after the marriage and after having children get access to power while the legal power over children is under the control of men (their father). Women in acquiring the transferring power consider female children as unable and bring up limited while respecting the male children and therefore the belief in cliché views from them leads to the normal consideration of the overhand power i.e. men and lower hand power i.e. women. (Azazi, 2001) and (Azazi, 2011) On the other hand the family and the internal relations have a private section ruling and many of the family data are not accessible. In terms of the women occupation regardless of the responsibility of men to be the breadwinner for the family the lack of congruity of the occupations with the prestige and sex tortures and lack of proportion against the men coworkers and lack of required qualification makes the occupation limited and weakens the financial and social independence of the women. (Azazi, 2011) From among the actions taken during the Pahlavi which led to the decline and in some case to prevent the rise of this discriminating status was the establishment of the judiciary system, increasing the security by the help of the city police and the foundation of working school, beneficiary hubs and the approval of laws to educated girls and support family. (Abrahamiyan, 2010) and (Abrahamiyan, 2013) Among them the interviews and the biographies of the women painters show that their fathers were mostly of high ranking clerks and has considerable role in an open minded way to encourage their attendance in social context and artistic tools and activities. They have usually referred to their tasteful fathers along with their traditional and tolerant mothers who have prepared the education and study and learning education for them and even have continued their support at higher ages. After fathers respectively brothers and sometimes husbands have had supportive roles and also more cautiously than fathers and cases after the death of the father or brother did not have a chance of an accompanying husband experienced divorce or permanent singleness and his shows that in masculine status of Iran in addition to legal support and having a modernist tasteful father and an encouraging brother and an accompanying husband had a significant role in the development of women painters.

\subsubsection{Education and Its Role in Boosting up the Role of Women}

Training and educating girls in the first years of Pahlavi continued the same as the last Ghajar era and the number of the girl schools increased in number but was not sufficient. And finally the parliament members in 1943 approved the compulsory primary education. This led to the rise of the number of literate people across the country. The rise of the girl institutes as well as the doubling number of the female student between1943-1948 and the improvement of women skills in addition to the improved social contexts shows the rise of the female education. (Dovorzhe, 1979) Education and improved social context and women skills development compared with their presence facilitated the non-private art training and official education. Official education and western 
style of painting from 1921-41in high schools of Iran and during the period leading to diploma and teachers training course became popular. (Torabifarsani, 1999) Two years after the establishment of Tehran University in 1938 the first group of women entered University. (Ettehadieh et al., 2011) Among them the establishment of the fine arts high school which had started from Tehran in 1918 by the establishment of the fine arts high schools of Tabriz, Isfehan, Rasht, Hamedan, and in two decades of 1950s and 1960s reached its acme. Painting, miniature, gilding and sculpture were among the most popular fields which were taught in them and the chance of education in these high schools was provided for the middle class urban girls. (mousavi, 2007) Finally in the year 1940 the fine art faculty was established, which was the first state school at high education level started activity. (Pakbaz, 2002) In respect and by the passage of time the attention to issues and the necessity of action $<$ ministry of education, religious contribution, and fine arts industries $>$, $<$ beautiful arts general office $>$ and $<$ culture and art ministry $>$ the Pahlavi era changed the art into a planned and possessing a responsible foundation. there were two contrastive tendencies existed during the official art of the Reza Shah art era. On one hand following the European academic art principles and on the other hand the attempt to revive the old miniature. The Ghahve Khane painting has also burgeoned beyond the official art procedure. Eclectic sculpture and architecture- the installment of the stature in urban settings-and attention to the pre-Islamic art era were also in fashion at that time and by the dismissal of the Reza Shah a new era of art was set on. (Pakbaz, 2002) Almost 70 years after the modernism movement in the west its reflections reached Iran and provided a chance for renovation in art areas. So that <open minded people" excitedly were in search of new ways, and their tempted curiosity, moved them towards trying different methods from impressionism to cubism, from surrealist fantasies up to imaginary formation. " (Yarshater, 1979)

Therefore, from the late 1941 by the expansion of the activities of modernist painters finally the attention of the cultural officials were attracted to them. The commencement of the first biennial exhibition of Tehran (1959) was the most significant action taken by the government to approve of the modernism movement (Pakbaz,2002) But the state and private support of the queen of artists and their activities in 1950s and 1960s reached its acme. So that the biggest number of the women painting exhibition was at the time of Pahlavi era was held in these two decades.

\subsubsection{Social Classes of Open Minded Class and the Political Discourses among Them}

Official system development and the literacy led to the emergence of the new non wealthy middle class which included the business professions, state clerks, military personnel, private sector clerks and technicians and the open minded people. The members of this group were the main actors of Pahlavi beget and changes. But despite the fact of the lack of political presence led to the disinterested feeling and consequently opposition against the regime among many members of this class and despite the attempts made by the Reza shah period to move women to societies the required changes had not been done to spread all parts of the society levels in this period despite the fact that because of the spread of a class of society which had less religious dependency was improved, but the power of religion remained for many families and the majority of the classes. (Ettehadieh et al., 2011) and (Foran, 1999) therefore, until before the September of 1941 the presence of women in offices was limited to literate and high ranking classes of the society. Economic problems and the financial needs of the late king Reza compelled the needy women to economic agencies. (Foran, 1999) many women were employed and religious groups who considered the working of women against the purity and dignity of the women and incited the men opposition (Anonymous, Bakhtar, 1941 ) and (Anonymous, Eettelaat, 1941). Indigence and desperation urged many of the poor class of the society to secretary, actress, singing and ballet or to vagrancy or prostitution. In fact one of the reasons why women entered into the opposition movement at this time was the extreme economic pressures. (Dovorzhe, 1979) May be the same changes and the creation of readiness in society allowed the democrat sect of Azerbaijan that after announcing autonomy although for a short period of time gave right of vote to the women. While the previous middle class had preserved their relation with the traditional culture of Iran the generations which matured after the kingship of the Reza shah were mostly westernized and had departed from the conventional culture and particularly the Islamic norm of behavior. Therefore, Nationalism and Marxism-the socialism discourse and the majority party- after the Second World War was popular among the open minded people. The end of the first Pahlavi era can be called the beginning of the democracy discourse in Iran that as a result of the Dr. Mosadegh and National front efforts. On the other hand in addition to the socialism discourse, democracy, autonomy discourse emerged at this time. The appearance of the new middle class and urban women and the presence of women in these three groups are undeniable. Generally, the new middle class in Pahlavi era had an apposite situation and life style And the western values of them were commensurate with the state intellectuals. By the departure of the king Reza from Iran new political activities emerged among the members of the middle class. After 1954 coup the Pahlavi government had problem to attract the support of the 
new middle class so that most of either opposed the government or doubted about it (Ashraf \& Bano Azizi, 2009) and (Bohrani, 2009) and (Kasravi, 1983) and (Bahar, 1978) and (Foran, 1999) Along with these three discourses and the support of the new middle class of them the Shia discourse and support of the clergy men had activities and most of the traditional middle class supported this trend. The fight of this discourse in the year 1960 during the land reform under the leadership of Imam Khomeini was started. (Jafariyan, 2003) and (Nozari, 2001) and (Karshenas, 2003) during the Pahlavi era the life standard of classes improved. But the difference in distribution of the resources led to deep inequities among the classes and regions. Therefroe, the level of women knowledge more or less depending on the class position experienced changes and led to the achievement of rights and privileges for women so that by the third bill of the association of the state and provincial in 1963 despite the opposition of Imam Khomeini and many of the Islamic groups women in opposition and by the decree of the king women got the right of vote and election in the associations (Anonymous, 1971) and (Toloei, 1993) and (Badamchiyan, 2005) Undoubtedly, the political situation of women in every society is a function of the rate of democracy in that society although by receiving this right of vote and the closed political atmosphere no conspicuous change of the rate of women cooperation occurred (Ettehadieh et al., 2011) but it was a huge step towards democracy. Political proclivities of the middle class-modern and traditional- except for the upper class as time passed were attempts towards achieving reforms or democracy in the ruling government. Most of the intellectuals and artists were from the new middle class and the women painters of the research subject mostly followed the political inclinations of this group. Despite all these national tendencies among such women a few of the women who were from the top level class by the occurrence of the 1979 revolution either did not understand the reasons behind it or did not consider it for the benefit of their party.

\subsubsection{Women and Religion and the Look of Islam to Art}

Although the women painters of the Pahlavi era in photos which are left from them in public contexts in proportion with the cultural-social policies of the government, sociability, and personal choices the same as many other fellow Iranians-co class-lack Islamic Hijab but this does not reduce the impact of religious view at the large scale of the society in their fate.

Clergymen as the most influential class by adding an amendment to the constitutional law had been able to enter the parliament as the supervisor to control the congruity of the bills with that of religion and preserve its control in the new regime. But in the secular policies of the Pahlavi, their number decreased to a considerable degree under the government and finally led to the political decline of them. During the second Pahlavi era Clergymen believed that the government is the puppet of the exploitation and on the basis of the negative view towards Exploitation and his action in strengthening Israel and Baheiat by the Pahlavi doubted every action made by the government and strongly opposed the extrajudicial activities of the government. (jamshidian \& parvane, 2012) and (Fozi, 2000) Among them and during the midst of the last century in addition to the support of the intellectuals of the women rights one of the most important factors on the position of the women the faith of the different Islamic creeds spectrums on women. in Quran oriented thought woman the same as man can evolve and reach the top and there is no reference to the mental deficiency of the woman and the mental deficiency of woman in quotation has been a very partial reasoning and if it is a general reasoning it is related to her emotions. (Quran) and (Ebne abitaleb, 2000) and (Motahari, 1996) and (Javadiye Amoli, 2007) Generally in Iran from creed perspective and not religious perspective there are two views towards women position. First the traditional view and second the religious reformists and religious intellectuals.

The traditional view is the most popular and oldest view during different Islamic periods. The first appearance of this outlook consists of many writings about women hijab and preventing them from mixing and attending at masculine scenes.

The opposition with establishing women schools and education, the rise of marriage age, the divorce right and occupation right are in line with it. This view is one of the most important aspects which limit the presence of women in society both because of the inclusion over the mentality of the public over the years and the proximity of this view to the power current over long periods. The enforcement and weakening this view depends on returns to the power and presence of the second view (Mehrizi, 2005 ) and (Ramezan Nargesi, 2004) and (Ettehadieh, 1994) The second view was formed from 1960s -1970s. by the publication of the Tafsir Almizan of the late Ayatollah Tabatabaei and the works of Morteza Motahhari and Dr. Ali Shariatei was started and then by the views of Ayatollah Khomeini entered a new period. The main features of this look might be listed as follows: defending the human identity of woman and equality with man, along with recognition of the differences between man and woman in terms of mental, physical and planning areas verbal statement and defending the women social cooperation authority and emphasizing on its priority 
In terms of the relation between Islam and art it can be claimed that traditional instructions of Islam did not have any special concern about art neither official rejection and abortion of the artistic activities nor positive views on the educational value of various softening artistic techniques. It can only be stated that according to Shia religious perspective Islam dos not oppose art by the condition that it does not waste time, cause corruption and temptation, loss of remembering God, tyranny against others but confirms it and does not consider gender limitation for the artist. The support of Islamic bases and principles from art and encouraging the committed artists by the religious forerunners and the creation of valuable and precious works in different periods of Islam all certify the importance of art in Islam. (Gerabar, 1995) and (Jannati, 1997) and (Hossieni, 1995) Generally, Muslim Iranian women in terms of the social activities since the constitutional revolution up to1960s had lots of confrontations with the traditionally oriented clergymen. But the emergence of the intellectual reformist religious people in 1960s decreased the angle of differences in between women movements and clergymen and religion in comparison with the last periods. (Bigdelo, 2012) From the constitution up to the end of the first Pahlavi, the role of the non Muslim women especially the Christian women in facilitating the apposite condition for the presence of Muslim women in educational and art fields are praiseworthy. The active presence of these women also Change of the rules of the religious law in terms of the hijab and socializing and mixing with men and their geography gets opened over the time. (khatoon Ghadami, 2012) and (Abdolhasan alghaffar, 1974) and (Dorant, 1957) and (Ancient Times Bible) and (Alimardi \& Alimardi ,2010) and (Mohammadi Ashnayi, 1994)

\subsection{Special Contexts}

\subsubsection{Queen and Cultural Policies in Support of Artistic Events and Foundations}

Although during 16 year kingship of Reza shah and in spite of the social changes women did not achieve general positions (Kar, 1997) but compared with that of previous kings the number wives of the king considerably decreased during the Pahlavi reign so that it can be stated that the permanent marriage of the king from polygamy converted into monogamy at second Pahlavi era and finally the role of the queen had a perfect legal and actual representation. $<$ Reza shah married four women respectively before becoming the king $>$ and it can be stated that except for the first marriage the rest of them were for increasing power and political nexus so that in the marriage of all his children he was in search of power. The law of uniform clothing -unveiling-even by force establishing educational system the right of women to attend at cinema and restaurant and even riding the coach in the first decade of his reign, acting in plays, publishing stamps with women figure, even singing, observing and be heard women as a conventional issue and eliminated many taboos. The presence and spread of girl scouting by the management of Shams Pahlavi in 1935 and also establishment and the impact of the women hubs and associations mostly dependent which were run by educated women institutionalized the presence of women in social spaces. (Bamdad, 1967) Attention to urbanization and urban spaces and press and magazines respectively foretld the creation of middle class and their habits. (Ori et al., 2009) A new type of consumption by the axis of individualism had become part of the citizens' habit; especially mode and make-up among the high ranking women of the society and court women had become a vogue for women. Except for the Tajol Molook other souses of king Reza interfered in political issue in order to bring up their relatives into power position and collect more wealth but she was mother of the crown prince and highly interested in western culture and in support of unveiling and especially after 1941 accompanied by her daughter Ashraf openly interfered in politics (Naseri Choblo, 2005) and (Rasooli \& Dolatshahi, 2002) and (Farahmand, 2003) By the marriage of Mohammad Reza two years before he becomes king Reza in 1939 with his first wife Foziye Foad another woman was added to the court.

The commuting of the king with the queen in public places and attendance at ceremonies such as second of May and fourth of October, was the beginning of explicit role of queen next to the king. After the divorce of Foziye because of disease and the threats of Ashraf the second wife of the king Soraya Esfandiari entered the court in 1950. (Solat Ghashgaei, 2005) There were less aggression towards her at court and she was more sociable than Foziye. Among them it should not be overlooked the high cost of attention to mode, clothes, hair dying and departure of jewelry from Iran at the acme of the second world war (Khalaj, 2008 ) Sorayya, as she mentions in her memories is among the ones who suggests the coup against Mosadegh (Amin \& Jadidi,2012) She has significant role in boosting up relation with Germany and America and was mostly the head of the alms associations and the deputy of the king in handling ceremonies (Anonymous, 1990) and finally because of disability of giving birth to a prince was separated from the king in 1958 and in 1960 Farah Diba as the third wife of the king and the last one in a perfect ceremony-with one million dollar Christian Dior clothes and hairdresser from Cartier - married Mohammad Reza

Farah was an architecture graduate from France from a normal family who was introduced to Mohammad Reza by Ardeshir Zahedi - CIA agent - That's why she is considered as the western agent. The similarity of Farah to 
the court in particular the king in not following ethical principles is the reason why she could remain in the court. Pahlavi court was full of unethical behaviors (Shokras, 1992) and (Shahbazi,1998) and (Masoud Ansari, 1992) As far as Abbas Milani writes quoting from Hoveida $<$ the government system was corrupt but the court was the home of the real viper> (Milani, 2001 ) and despite all of them Farah Diba by the birth of the prince became the queen of Iran in 1961 and crowned in 1968. She as the second person of the country was called Shahbanoo and has lots of authorities. Farah can be considered as the most influential and effective queen in terms of culture and art of the Pahlavi era. Organizations such as though training, fine art administration, book translation and publication foundation, and Pahlavi foundation, were among the most important political cultural foundations before Farah. But by the presence of Farah over the 1960s and 1970s more than 17 cultural and artist association and organization, 14 hygienic and treatment center, and 8 educational and university centers were founded that she personally made attempts or managed them such as Tehran Philharmonic association 1964, Iran culture foundation 1965, children and teens intellectual training hub 1966, Iran National Cultural Relations Associations 1967. Iran National Folklore Organization and Roodaki hall 1968, City Theater hall 1973, and Imperial Philosophy Association 1974, in the years 1963-1979 holding the festivals and ceremonies such as Shiraz art festival, Toos festival, Ballet, Opera, and film festivals were on the rise and (Zonis, 1991) and (Kasra,2001) and (Samimi, 1984) and (Abrahamiyan, 2013) and (Ori et.al., 2009) designing and constructing places such as Contemporary Art Museum, Niyavaran Cultural Center, supreme girl school, Iran's tombs of fame figures and educational and welfare issues are among the activities done during her reign and under her supervision (Pahlavi, 2005) The second Pahlavi era is the period of several art galleries in Tehran of that time. Apart from Apadana (1949) and Honare Jadid (1957) galleries more than 22 galleries were established during Farah And were run privately or by the government and the queen took part in their inauguration day and their exhibition. From among them we may refer to: Kabood, Talare Iran (Ghandriz), Boorgez, Seyhoon, Negar, Niyazi, Talare Naghsh, and etc these activities by Farah despite considerable social class contradictions, financial and official corruption and unequal distribution of economic resources and extravagant tendencies towards luxury in court has an effective role in providing access to educational and cultural spaces and occupational enforcement and visual stamina of the artists and correcting the face of Pahlavi.

\subsubsection{Social Activities and the Advantages of Urbanity}

As mentioned earlier the women painters were fully urban and had spent their adolescence in Tehran. Tehran from the early Ghajar era enjoyed both the advantages and disadvantages of being the capital city and among its advantages in addition to paying attention to urbanity, telegraph, academy, was permitted, publication, parliament and court the proximity to political power and economic force and lawmaking. In 1926 by the crowning of Reza shah Tehran witnessed a new era. Although Tehran was not all of Iran but we might say that the history of the past two centuries has passed in Tehran and it has been mixed together. Reza shah provided western educational foundation, western like women working outside the house, modern economic structure of administration, state run factories, connection networks, financial banks, large stores, by nonreligious making, fight against racism, nationalism, the expansion of state education and financing. So that the population of Tehran from 196255 people in 1921 increased to 700000 people in 1941 (Abrahamiyan, 2013) urbanity has an ascending move so that in $1979,46 \%$ of the country population lived in urban centers and Tehran had the highest rate of rural migration. (Abrahamiyan, 2010) the concentration of different women association such as women organization and the Zolfagar party was in Tehran. Tehran with $20 \%$ of the country population in the midst of the 1970s decade had more than $50 \%$ of the hygienic and educational facilities and occupational and welfare facilities. (Abrahamiyan, 2010) For example in 1975 Tehran had 119 cinema and cities like Esfehan had only 12 cinemas. (Ori et.al., 2009). Education, occupation and social security had been able to affect the social context spectrum of women access to it but occupation was an influential factor which sustained the presence in society after education.

In this decade on one side <the ratio of all women who entered occupation and education increased. In the year: 1976 the rate of women literacy was $35 / 7 \%$ and $11 / 3 \%$ of urban women had entered the occupation on the other hand the unequal pattern remained stable. The literacy of the women in comparison with the literacy arte of men $74 / 7 \%$ and the low rate of the economic activities with the cooperation rate about $90 \%$ of men in this year women had 30\% of the high education (Ettehadieh,2011) and finally across Iran <in 1979 two million Iranian women were present in occupation and 187928 people had registered for academic and university subject and among them 1666 managers and 1803 university professor> (Afkhami,1984) and this number despite the small number gave a cooperative face to the cities of Iran and women painters thanks to dwelling in Tehran had a chance to make use of such cultural and civil spaces. 


\subsubsection{Publicizing the Culture and Mass Media}

Over the Pahlavi era by considering the <party orientation>, the income rate of people, nation wide access, illiteracy and the rise of social class contradiction of influential media in order of priority press, radio, cinema and finally television, that we analyze them later in the work. Although during the Reza shah the press number had a falling move but the press became an event for the middle class families. $60 \%$ of the press were sold in the city centers and the rest of them in Tehran (Ori et al., 2009). After the departure of Reza shah in 1941 only 10-15\% of the people were able to read and write and the volume of the papers were usually low. 1940s was full of chaos for the press (Ori et al., 2009). Mass media by the rise of the oil price had a considerable growth and the number of radio from two to four million and television from 120000 to 1700000 devices and the number of sold cinema tickets from 20 to 110 million (Abrahamiyan, 2013). 1960 and 1970 decades witnessed the increasing expansion of western culture in Iran. This culture was one of the principle bases of the idea of contemporary Iranian identity making in Pahlavi government (Samimi, 1984) The Iranian press in 1960s and 1970s presented western patterns and western singers and actresses became the model of Iranian youths and women (Alini, 1995) although Iranians were familiar with radio from 1982 but Tehran radio station was established in 1940. The silence of the last months of Reza shah by the speech of his son from radio was broken most of the radio popularity was among People and transistor radio import. People were familiar to listen to radio to get the news therefore radio was quickly welcomed by the public. While the number of illiteracy had reduced but people preferred to listen rather than read (Kaveh, 2008 ) and (Hosseini Pakdehi, 2007) and (Porsam, 2009). In terms of the Reza shah cinema it can be said that the films were about the crowning of Reza shah and railroad inauguration and the establishment of the national bank along with the public presence the unveiling decree increased the number of women spectators. Following the presence of women Dr, Esmaeel Kooshan in 1950 $<$ Shameful $>$ was made and gave the firs role to a very famous singer Delkash this film was very successful and its weak structure was the basis for several other films which were made very quickly. Singing and dancing was the two basic part of these films (Ori et al., 2009). The analysis of the titles of the films of this period show that the word girl created more sexual temptations on the announcement and advertisement boards which were sexually more attractive were used more than other words the other film which was for years the pattern fill was the Ghanje Gharoon by Siyamk Yasemi in 1966 by the first role of the former wrestler Mohammad Ali Fardin attention to first role actor started with Fardin and ended with Behrooz Vosooghi. Dubbing technique was a privilege which was brought to Iran after the second world war and beside screening foreign films assisted Iranian film industry (Ori et al., 2009). After that we see that local cinemas from the midst of the 1970s are considered as a social event and different conditions of different places cause screening difference between Tehran and other cities. In Tehran during the days women and girls go to cinema with their men relatives and at night men constitute the majority of the spectators, especially in towns. Despite the artistic posters prepared by Iranian Graphic designers unfortunately most of the notes and advertisements by the cinema entrance were empty and tempting pictures (Ori et al., 2009). at the beginning of the 1970s decade because of the inflation the production process declined and while at the beginning of the twentieth century film was the entertainment of the higher class of the society from the midst of the 1970 s film became the entertainment of the lower level class. Generally it seems that designing entertainment is no planned for the rural dwellers (Ori et al., 2009). while TV entered Iran in 1954 national TV and radio organization started in 1967 this organization by various performance should be prized and valued for the programs that have revived and displayed the traditional art and life style of Iran up to the late 1970s. The number of the art festivals and research institutions educational facilities which were established and managed by the national television is highly admirable. On the basis of the statistics 1979 four million families were under TV coverage, while only 1/7 million had TV (Ori et al., 2009). and this number show the luck of it. By the help of mass media the publicizing of the culture-along with westernization-cultural history of Iran was changed by lots of text and image over half a century. Women painters on the basis of the family had the access to them. They passed their childhood with gramophone, book and visual magazines, teen with colorful magazines, music and radio and cinema and youth with television and opera and ballet and were brought up by an artistic culture.

\section{Conclusion}

After centuries of being disregard the incited importance of women by means of constitutional revolution moved them out of the inside to schools and associations and woke up the demanding nature in them. By the presence of Pahlavi and top-down activities and based on westernization and non-religious method and archaism and anti racism along with ruling international atmosphere especially after world wars women were able to make use of more expansive urban spaces and facilities and social position under the protection of law and boost up their political cooperation so that it was reflected in the role of the queen as the second person of the country with 
legal validity and she according to cultural policies although late and developmental activities to improve cultural spaces and introducing the art and artists of Iran to the world. Although these activities in cases were abused because of the costs and lack of social position among the public led to sexual confrontation and diversions with physical and material contact with women brought about complaints but were not ignorable. In this socially provided context from the higher and middle class - far away from the sorrow of lack of bread- and girls who had a chance to be born in these families and had a hand and heart in such art works were able to make use of the official educational art classes up to high and academic education. Before anything else, these women had modernist fathers and courageous mothers that one of them opened the development path for them and the other waned the civil experiences and share demand for them. Mostly fathers and brothers and sometimes husbands as a traditional spouse and a modernist father made attempts to open up openings for their growth despite the extreme masculinity. The presence of various mass media, along with rise of access to the educational and cultural centers and enforcement of the visual memory led these girls to be women trained by art culture and overcome obstacles by tireless effort as a child, spouse and mother, and hang their works on the walls of the galleries. 166 women, in 12 years in 24 galleries. Undoubtedly the number of them is much more than this and women whose share of the civil life is undeniable.

\section{References}

Aazazi, S. (2001). family violence beaten women (Eds). Iran, Tehran: Sali.

Aazazi, S. (2011). change of women role. (Eds). Iran, Tehran: Elm.

Abdolhasan alghaffar, A. (1974). Almerah Almoasere (Eds). Lebanon, Beyrot: Darolzahra.

Abrahamiyan, Y. (2010). Modern history (6th ed). (Mohammad Ebrahimfatahi, Trans.). Iran, Tehran: Ney.

Abrahamiyan, Y. (2013). Iran between two revolution (20th ed). (Ahmad Golmohammadi \& Mohammad Ebrahimfatahi, Trans). Iran, Tehran: Ney.

Afkhami, M. (1984). Iran: A Future in the past, The "Pre-revolutionary" Women's Movement. In Robin Morgan (Ed.), Sisterhood Is Global. Garden City: Anchor Books.

Alimardi, M., \& Alimardi, M. M. (2010). hijab, and coverage in Zoroaster, Jewish and Christianity. Religions Cognizance Magazine, 3, 127.

Alini, M. (1995). Iranian press from coup to revolution. Media e,1,60.

Amin, M., \& Jadidi, M. (2012). Queen Soraya" report of the sorya from the mosadeg coup". Hafez, 96, 22.

Ancient times. Travel of Torihe mosana. Chapter. 22. Paragraph. 5.

Anonymous (1990). Iran and Islam in German magazine. Yad, 18, 70-72.

Anonymous. (1941, December 8). street protest in Tehran. Eettelaat, 4701, 3.

Anonymous. (1941, January 7). News. Bakhtar, 591, 3.

Anonymous. (1971). Iranian woman from farmland to ministry (Eds). Iran, Tehran: Iranian women organization.

Ashraf, A., \& Bano Azizi, A. (2009). Social classes, government and revolution in Iran (2nd ed). (Soheyla Torabifarsani Trans.). Iran, Tehran: Nilofar.

Badamchiyan, A. (2005). Familiarity with the coalition community of Islamic (Eds). Iran.Tehran: Andishe Nab.

Bahar, M. T. (Malekolshoara). (1978). brief history of the political parties of Iran (Eds.), (Vol. 1). Iran,Tehran: Pockect Size Press.

Bamdad, B. (1967). Iranian woman constitutional revolution to white revolution (Eds). Iran,Tehran: Ebnesina.

Bigdelo, R. (2012). Government and state confrontation, about second period of Pahlavi era (a case study of zane rooz magazine in 40s and 50s decades). historical and Islamic research of Islam, 11, 20-26.

Bohrani, M. H. (2009). Middle class and the changes in contemporary Iran (2001-1941) (Eds). Iran, Tehran: Agah.

Dorant, W. (1957). history of the civilization (Eds). (Ahmad Aram and et al Trans.). Iran, Tehran: Egbal Franklin.

Dovorzhe, M. (1979). Political Sociology (Eds.), (Abolfazlgazi Trans.). Iran, Anonymous, Javidan Press.

Ebne abitaleb, A. (2000).Nahjolbalage (Eds.), " $80^{\text {th }}$ Sermon". (Mohammad Dashti Trans). Iran, Gom: Safhe Negar. 
Ettehadieh, M. (1994). woman in Ghajar society "the position of women in society at the beginning of $14^{\text {th }}$ century". Kelk Mgazine, 55 \& 56, 27-50.

Ettehadieh, Mansoreh and some of the scholars women essay collection. (2011). woman in contemporary Iran history (Eds.). Iran,Tehran: Kavir.

Farahmand, J. (2003). Court 's Diplomacy. Iran's Contemporary History Magazine, $28,207$.

Foran, J. (1999). Fragile resistance, social evolution in Iran after Safaviyeh to the years after the Islamic revolution (2nd ed.) (Ahmad Tadayon Trans.). Iran, Tehran: Rasa.

Fozi, Y. (2000). Religious leaders and modernism in Iran in second Pahlavi era (first part). Matin Research Magazin, 9,161-168.

Geraber, E. (1995). Islam and visual arts, (Rahim Mosavinia Trans.). Art Quarterly Magazin, 238, 20-23.

Hosseini Pakdehi, A. (2007). Radio - Television public service; the concept, features, historic back ground and the causes of the crisis in two last decade of 20 century. Media Magazine, 71, 119-154.

Hossieni, S. A. (1995). Religious Jurisdiction, and Visual art. Religious Jurisdiction and Principles, 4\&5, 17-33.

Jafariyan, R. (2003). Religious and political movements of Iran in 1940 and 1979 (Eds.). Iran,Tehran: Islamic Culture and Research Center.

Jamshidian, S., \& Parvane, Nader. (2012). The crisis of legitimacy and the position of clergy men in Firs Pahlavi, Historic Research Magazine ,51,111-106.

Jannati, M. E. (1997). Study of beauty and art by modern method of interpretation. Islamic Studies Magazine, 10 \& 11, 48-85.

Javadiye Amoli, A. (2007). woman in beauty and dignity (3rd ed.) (research and arrangement Mahmood Latifi, Saeed Bandali Editor.). Iran, Gom: Irae.

Kar, M. (1997). Political Rights of Women (Eds.). Iran, Tehran: Roshangaran and Women Studies.

Karshenas, M. (2003). Oil, Government and Industrialization in Iran (Eds.) (Ali asgari and Yusef Haji Abdolvahhab Trans.). Iran, Tehran: Game No.

Kasra, N. (2001). Influential women of Pahlavi dynasty (2nd ed.). Iran, Tehran: Namak.

Kasravi, A. (1983). 18 year history of Azerbaijan (Eds.). Amirkabir, Tehran.

Kaveh, G. (2008). A review of the radio history in Iran. Social Science Book, 8, 64-78.

Khalaj, M. (2008). Court Women in Second World war. Historic Studies, 21 ,60-73.

khatoon Ghadami, H. (2012). Woman in Sacred Books: Woman in Christianity. Mahe Din Book, 179, 30-36.

Masoud Ansari, A. A. (1992). After decline (Eds.). Iran, Tehran: Political Research and Studies Center.

Mehrizi, M. (2005). Religious Views of Woman. Aeineh Pajoohesh magazine, 91, 8.

Milani, A. (2001). Hoveida puzzle (3rd ed.). Iran,Tehran: Atiye.

Mohammadi Ashnayi, A. (1994). Hijab in divine religions (Eds.). Iran, Ghom: Eshragh.

Moska Gaeta, B. (1991). History of the Beliefs and Political Policies (2nd ed.). (Hossein shahid zade, Trans.). Iran, Tehran: Morvarid.

Motahari, M. (1996). Women Rights System in Islam (143 th ed.). Iran, Ghom: Hekmat.

Mousavi, H. (2007). Look at The High School of Painting in Iran. Aeine Khiyal, 5, 77-70.

Naseri Choblo, A. (2005). Tiger of The Court. Zmaneh, 40, 32-34.

Ori, P., Hambli, G., \& Melvil, C. (2009). Iran Cambridge History (Eds.). (Teymor Gaderi Trans.). Pahlav 3 th part. Iran, Tehran: Mahtab.

Pahlavi, F. (2005). An Enduring Love: My Life with The Shah. A Memoir. New York, NY: Miramax .

Pakbaz, R. (2002). Art Encyclopedia (3rd ed.). Iran, Tehran: Farhange Moaser.

Porsam, Z. (2009). The History of The Changes of Radio in Iran. Social Science Magazine, 24, 42-43.

Quran. Ahzab Sura. Ayah 35.

Ramezan Nargesi, R. (2004). The Impact of Shia creed on the identity of the Iranian woman. Shia women, 1, 140-199. 
Rasooli, M., \& Dolatshahi, E. O. (2002). Pahlavi dynasty, from one of the Reza shah spouses, an interview with Esmatol molook Dolatshahi. Contemporary History of Iran, 23, 325-328.

Samimi, M. (1984). Back of the Takhte Tavoos (2nd ed.) (Aboo Torabian Trans.). Iran, Tehran: Ettelaat.

Shahbazi, A. (1998). King Guardian (Eds.). Iran, Tehran: Ahle Ghalam.

Shokras, W. (1992). The Last Trip of The King (4th ed.) (Abdolreza Hoshang Mahdavi ,Trans.). Iran,Tehran: Alborz.

Solat Ghashgaei, M. N. (2005). The Reasons of Foziye Divorce, Quoted by Dr. Ghasem Ghani. Hafez Magazine, $21,69-70$.

Toloei, M. (1993). Father and son untold of the life from the tile of Pahlavis. Iran,Tehran: scientific pub.

Torabifarsani, S. (1999). Documents from girl schools from Mashroote to Pahlavi (Eds.). Iran, Tehran: National Documents Organization .

Yarshater, E. (1979). Contemporary Persian Painting. In R. Ettinghausen \& E. Yarshater (Eds.). New York, NY: Highlights of Persian Art.

Zonis, M. (1991). Kingly Defeat; Considerations about the Fall of the King (Eds.). (Esmail zand And Batol saidi Trans.). Iran,Tehran: Noor.

\section{Copyrights}

Copyright for this article is retained by the author(s), with first publication rights granted to the journal.

This is an open-access article distributed under the terms and conditions of the Creative Commons Attribution license (http://creativecommons.org/licenses/by/3.0/). 